PROBLEMS

OF EDUCATION

IN THE $21^{\text {st }}$ CENTURY

Volume 51, 2013

126

PROSPECTIVE CHEMISTRY TEACHERS'

PROBLEM SOLVING ACHIEVEMENT ACCORDING TO THEIR LEVELS OF METACOGNITIVE SKILLS

\author{
Senar Temel \\ Hacettepe University, Ankara, Turkey \\ E-mail: senar@hacettepe.edu.tr
}

\begin{abstract}
This research aims at analysing how prospective teachers' levels of metacognitive skills influence their problem solving achievement. The research was conducted with the participation of the 32 prospective teachers attending the Department of Chemistry Education of the Education Faculty of Hacettepe University and enrolled in Inorganic chemistry course in the 2010-2011 academic year. Metacognitive Activities Inventory, MCA-I and Chemical Bonding Achievement Test, CBAT were used as the tools of data collection. Descriptive statistics as well as one-way ANOVA were employed in the analysis of the data collected. Consequently, the prospective teachers were divided into three groups according to their levels of metacognitive skills. Following the one-way ANOVA, it was found that there were no statistically significant differences between the prospective teachers grouped on the basis of differing levels of metacognitive skills in terms of their achievement in problem solving.
\end{abstract}

Key words: achievement, metacognition, problem solving.

\title{
Introduction
}

The first goal of science education is to obtain the knowledge organised in a special field and the second is the problem solving skill related to the field (Gabel \& Bunce, 1994; Heyworth, 1999; Stamovlasis \& Tsaparlis, 2000; Tsaparlis, Kousathana \& Niaz, 1998; quoted by Lee, Tang, Goh \& Chia, 2001). Differing definitions of problem solving are available in literature. Problem solving is the process of an individual's challenging the obstacles that he/ she encounters (Temel \& Morgil, 2012). According to Wheatley (1984), it is what you do when you do not know what to do. Problem solving may be thought just like way-finding through a labyrinth. While moving in a labyrinth, advance towards the targeted end-point is made, and wrong moves are also made in this process. Then, what it is that guides you through your choices? Probably the answer is choosing the process which seems to lead to the goal, or it is the use of strategies. Strategies are the best guides in problem-solving, and they help to attain the target. If the problem solver wishes to achieve in the problem solving process, he or she should be aware of the targets, the strategies used for attaining the targets, and the effects of the strategies; because the most general property of problem solving is the individual's capacity to control and monitor his or her own thoughts. Such a self-monitoring is known as metacognition (Martinez, 1998).

Metacognition is an individual's ability to be aware of his/her own thinking processes and to control them (Özsoy, 2007). Senemoğlu (2011) believes that being aware of how something is learnt in addition to learning it is to know how it is learnt. According to Brown (1978), what students employ in planned learning and in problem solving is awareness of thinking processes and organisation of those processes. Such abilities as being aware of the learning process, planning, choosing strategies, monitoring the learning process, correcting the mistakes, controlling 
whether or not the chosen strategy works, changing the learning methods and strategies when necessary constitute the metacognitive skills (Özsoy, 2006). Not only do they help to solve a given problem, but they also contribute to the solution of similar problems and thus facilitate the learning transfer (Veenman, Elshoutt \& Meijer, 1997).

\section{Importance of Research}

Metacognition was stated as one of the basic elements used in the problem solving process, and metacognitive skills were described by researchers (Flavell, 1979; Sandi-Urena, Cooper \& Ron, 2011) as one of the most important factors in explaining the achievement in problem solving. Students with high levels of metacognitive skills are known to display better performance in problem solving. It was observed that such students behaved in a controlled manner all through the problem solving process, they tried to solve the problems by dividing them into simpler pieces, and that they asked themselves questions so as to make their thoughts clear (Özsoy, 2006). Several researchers pointed out that there was a significant correlation between metacognitive skills and problem solving achievement, and that the teaching of those skills would raise achievement in problem solving, and thus students would organise mental processes in a more efficient way (Desoete, Roeyers \& Buysee, 2011; Kapa, 2001). Cooper and Sandi-Urena (2009), on the other hand, stated that metacognition was a basic component both in chemical achievement and in the development of problem solving skills. Yet, the fact that the number of research studies conducted in the field of chemistry education related to problem solving and metacognition is limited explains the reason for performing this current research.

\section{The Aim of the Research}

This research aims to examine how prospective teachers' levels of metacognition skills influence their problem solving achievement. Based on this aim, answers are sought to the following questions:

1. At what level are the prospective teachers in terms of metacognitive skills?

2. Is there a statistically significant difference between the prospective teachers grouped on the basis of differing levels of metacognitive skills in terms of their problem solving achievement?

\section{Methodology of Research}

This research is a causal-comparative research. The aim of this type of research is to determine the cause of existing differences among groups.

\section{Sample of Research}

A total of 32 prospective teachers attending the Department of Chemistry Education of the Education Faculty of Hacettepe University and enrolled in Inorganic Chemistry course in the 2010-2011 academic year participated in the research.

\section{Instruments}

1) The Inventory of Metacognitive Activities (MCA-I): The inventory developed by Cooper and Sandi-Urena (2009) was translated and adapted into Turkish by Temel, Dinçol and Y1lmaz (2011). Following the factor analysis, the inventory was found to have four factors and the Cronbach Alpha coefficient was calculated as 0.92. The inventory is a 23- item, 5-pointed Likert type scale. It is used for the evaluation of students metacognitive skills, and it informs us of what they think during problem solving and of what they actually do while they are solving a problem. 
ROBLEMS

OF EDUCATION

IN THE $21^{\text {st }}$ CENTURY

Volume 51, 2013

2) The Chemical Bonding Achievement Test (CBAT): The test which was used for the evaluation of students' problem solving achievement in chemical bonding was prepared by Temel, Dinçol and Y1lmaz (2011). Efforts were made to perform the content validity of the test through field experts' check. The Cronbach Alpha reliability coefficient for the test containing 10 conceptual problems having the sub-topics "types of bonds, bond angles, hybridization, molecule shapes, polarity, and nonpolarity" was calculated as 0.82 .

\section{Procedure}

This research was performed in Inorganic Chemistry classes. The prospective chemistry teachers were knowledgeable in terms of chemical bonding from both General Chemistry and Inorganic Chemistry courses.

1. The prospective teachers were first informed of the purpose of the research.

2. The prospective teachers were given the CBAT test of 10 conceptual problems.

3. One week after administering the test, the MCA-I was applied.

4. The data obtained from the test and from the inventory were then analysed.

\section{Data analysis}

Descriptive statistics (mean score and standard deviation) and one-way ANOVA were used in the analysis of the data. The grouping method which was developed by Cooper, SandiUrena and Stevens (2008) was used in the analyses of the data obtained from the MCA-I. According to this grouping method, the MCA-I scores are divided into three groups:

- A low or "L group"; those participants below the mean score minus one standard deviation,

- A high or "H group" participants with scores above the mean score plus one standard deviation,

- An intermediate or "I group" composed by those whose score is between these extremes.

\section{Results of Research}

Firstly, the prospective teachers were divided into 3 groups according to the grouping method of Cooper, Sandi-Urena and Stevens (2008). Prospective teachers' mean score of metacognitive skill is $\bar{X}=3.78$ and standard deviation is $\mathrm{SD}=0.48$. According to these values, MCA-I scores are divided into three group as shown in Table 1.

Table 1. Prospective teachers' distribution according to their probable metacognitive skill groups.

\begin{tabular}{|c|c|}
\hline Probable metacognitive skill groups & Number of students (N) \\
\hline High group (H-Group) & 7 \\
\hline Intermediate group (I-Group) & 18 \\
\hline Low group (L-Group) & 7 \\
\hline
\end{tabular}

Secondly, so as to see whether or not there was any significant difference between the problem solving achievement of prospective teachers who had been grouped according to their levels of metacognitive skills, one-way ANOVA analysis was performed. The findings obtained are shown in Table 2. 
Table 2. The ANOVA results for prospective teachers' problem solving achievement according to their levels of metacognitive skills.

\begin{tabular}{|c|c|c|c|c|c|}
\hline Source & Sum of Squares & dr & Mean Square & F & P \\
\hline Between groups & 1.446 & 2 & 0.723 & & \multirow{2}{*}{0.218} \\
\cline { 1 - 3 } Within groups & 96.429 & 29 & 3.325 & & \\
\cline { 1 - 3 } Total & 97.875 & 31 & & & \\
\hline
\end{tabular}

Examining the analysis results in Table 2, it is clear that there is no significant difference between the problem solving achievement of prospective teachers who were grouped according to their levels of metacognitive skills $\left[\mathrm{F}_{(2-29)}=0.218, \mathrm{p}>0.05\right]$.

\section{Discussion}

In this research, firstly, the prospective teachers' levels of metacognitive skills were determined. As is clear from Table 1, they were divided into three different groups of metacognitive skills. 7 students were placed in the high metacognitive skills group while 18 were in the intermediate group and 7 were in the low group. Generally, it can be said that their level of metacognitive skill is in intermediate level. Secondly, analyses were made so as to see whether or not there was any significant difference between the problem solving achievement of prospective teachers who had been grouped according to their levels of metacognitive skills. As is evident from Table 2, there is no significant difference between the problem solving achievement of prospective teachers who were grouped according to their levels of metacognitive skills $\left[\mathrm{F}_{(2-29)}=0.218, \mathrm{p}>0.05\right]$. Besides, it was also found that the prospective teachers' mean scores of problem solving were L-Group ( $\bar{X}=5.60$ ), I-Group ( $\bar{X}=5.90$ ), and H-Group ( $\bar{X}=6.28$ ). The achievement of those in the H-Group was the highest of the three whereas the achievement of students in the L-group was the lowest, but the differences were found to be insignificant. A review of literature showed that research studies with findings which were not consistent with ours were also available. Desoete, Roeyers and Buysee (2011); Kapa (2001) found that there were significant correlations between metacognitive skills and problem solving achievement, and that the teaching of those skills raised the achievement in problem solving and thus students could organise the mental processes in a more effective way. Swanson (1990) revealed that students with higher levels of metacognitive skills displayed better problem solving performance than those with lower levels of metacognitive skills. In their study, Cooper, Sandi-Urena and Stevens (2008) concluded that groups of students who performed using more metacognitive strategies had significantly higher mean MCA-I values than those using fewer metacognitive strategies. Sandi-Urena, Cooper and Ron, (2011) found that compared to the control group, the treatment group showed a significant increase in metacognition awareness, as evidenced by the MCAI, increased ability in solving nonalgorithmic chemistry problems of higher difficulty, and with a higher per cent correctness.

\section{Conclusions}

The findings obtained in this research reflect the prospective teachers' current state in terms of metacognitive skill. Generally, their level of metacognitive skill is in intermediate level. After they were grouped according to their level of metacognitive skill, it was also found that the achievement of prospective teachers' in the H-Group was the highest of the three whereas the achievement of students in the L-group was the lowest, but the differences were found to be insignificant. Since metacognitive approaches to developing problem solving skills need a long-term intervention (Hollingworth, 2001), such a study could be done with an application focusing on problem solving achievement in a longer time scale, and the variables in the re- 
PROBLEMS

OF EDUCATION

IN THE $21^{\text {st }}$ CENTURY Volume 51,2013

130 search could be re-analyzed. Because if the students notice that they have some problem solving skills, that they are clearly taught those skills in a discipline, and that they are encouraged to develop their metacognitive awareness, this will result in acceleration in the learning process, learning the new knowledge more easily, and the increase in academic performance (Hollingworth, 2001). Therefore, learning environments should be organised for prospective teachers which provide them opportunities to control their own learning process, to take on responsibilities in this process, and to do all these through problem solving applications which are offered. Also to remove the limitation of this research, these variables can be examined with studying larger sample in future studies.

\section{References}

Brown, A. L. (1978). Knowing When, Where, and How to Remember: A Problem of Metacognition. In R. Glasser (Ed.), Advances in Instructional Psychology. Hillsdale, NJ: Lawrence Erbaum.

Cooper M. M., Sandi-Urena S., \& Stevens, R. (2008). Reliable multi method assessment of metacognition use in chemistry problem solving, Chemistry Education Research and Practice, 9, 18-24.

Cooper M. M., \& Sandi-Urena, S. (2009). Design and validation of an instrument to assess metacognitive skillfulness in chemistry problem solving. Journal of Chemical Education, 86 (2), 240-245.

Desoete, A., Roeyers, H., \& Buysee, A. (2011). Metacognition and mathematical problem solving in Grade 3. Journal of Learning Disabilities, 34 (5), 435-449.

Flavell, J. H. (1979). Metacognitive and cognitive monitoring: a new area of cognitive developmental inquiry. American Psychologyst, 34 (10), 906-911.

Hollingworth, R. (2001). The role of computers in teaching chemistry problem solving. Chemical Education Journal, 5 (2).

Kapa, E. (2001). A metacognitive support during the process of problem solving in a computerized environment. Educational Studies in Mathematics, 47, 317-336.

Lee, K. W. L., Tang, W. U., Goh, N. K., \& Chia, L. S. (2001). The predicting role of cognitive variables in problem solving in mole concept. Chemistry Education Research and Practice, 2 (3), 285-301.

Martinez, M.E. (1998). What is problem solving?, Phi Delta Kappan 79 (8), 605-609.

Özsoy, G. (2006). Problem çözme ve üstbilis. Ulusal Sinıf Öğretmenliği Kongresi Bildirileri (Ankara, Gazi Üniversitesi, Mayıs-2006) (Cilt II.). Ankara: Kök Yayıncılık.

Özsoy, G. (2007). Illköğretim besinci sinıfta üstbilis stratejileri öğretiminin problem çözme başarısına etkisi. Yayımlanmamış doktora tezi, Gazi Üniversitesi, Ankara.

Sandi-Urena, S., Cooper, M. M., \& Ron, H. S. (2011). Enhancement of metacognition use and awareness by means of a collaborative intervention. International Journal of Science Education, 33 (3), 323-340.

Senemoğlu, N. (2011). Gelişim öğrenme ve öğretim: Kuramdan uygulamaya (20. Bask1.) Ankara: Gazi Kitabevi.

Swanson, H. L. (1990). Influence of metacognitive knowledge and aptitude on problem solving. Journal of Educational Psychology, 82 (2), 306-314.

Temel, S., Dinçol, S., \& Y1lmaz, A. (2011). Metacogniton und problemlösen. GDCh Science Forum Chemistry "Chemistry Creates Future", Bremen: 4-7 September,

Temel, S., \& Morgil, I. (2012). Kimya laboratuvarında problem çözme uygulamaları. Ankara Üniversitesi Ë̌itim Bilimleri Fakültesi Dergisi, 45 (2), 55-76.

Veenman, M. V. J., Elshout J. J., \& Meijer J. (1997). The generality vs. domain-specificity of metacognitive skills in novice learning across domains. Learning and Instruction, 7 (2), 187-209.

Wheatley, G. H. (1984). MEPS Technical Report, Mathematics and Science Centre, Purdue University. 
Senar TEMEL. Prospective Chemistry Teachers' Problem Solving Achievement According to Their Levels of Metacognitive Skills

PROBLEMS

OF EDUCATION

IN THE $21^{\text {st }}$ CENTURY

Volume 51, 2013

131

Senar Temel Dr., Expert, Hacettepe University, Faculty of Education, Department of Chemistry Education, Ankara, Turkey.

E-mail: senar@hacettepe.edu.tr 